\title{
Factors affecting the failure of exclusive breastfeeding practice: a scoping review
}

\author{
Sulasmi a,1.*, Mufdlilah ${ }^{\text {b,2, }}$, Luluk Rosyida ${ }^{\mathrm{c}, 3}$ \\ ${ }^{a}$ Master Program in Midwifery, Health Science Faculty, Universitas ‘Aisyiyah Yogyakarta, Indonesia \\ b,c Lecturer at University 'Aisyiyah Yogyakarta, Indonesia \\ ${ }^{1}$ sulasmi.ami02@gmail.com*; ${ }^{2}$ mufdlilah@ unisayogya.ac.id; ${ }^{3}$ rosidalulu@gmail.com \\ * corresponding author
}

\section{ARTICLE INFO}

\section{Article history}

Received, $3^{\text {-st }}$ July 2021

Revised, $15^{\text {th }}$ October 2021

Accepted, 29-th November 2021

Keywords

Failure

Exclusive Breastfeeding

\section{ABSTRACT}

Background: In some countries, exclusive breastfeeding is practiced in a limited number of cases and for a short period of time; on an international scale in 2012, only $39 \%$ of six-month-old babies were exclusively breastfed. This breastfeeding rate falls short of the World Health Organization's recommended threshold (WHO). According to WHO, to reach the global level by 2025 , which is $50 \%$ of mothers must exclusively breastfeed for 6 months after giving birth, a strategy must be developed to encourage and facilitate the initiation and continuation of breastfeeding. So, it is hoped that with the target set by WHO, mothers can give breast milk exclusively to their babies for 6 months optimally. Exclusive breastfeeding (ASI) is the ideal nutrition for babies in the first 6 months of life, with continued breastfeeding being recommended for up to 2 years of age. The health benefits of selffeeding are dose dependent, and infants with longer periods of exclusive breastfeeding have better health outcomes. The benefits of breastfeeding are dose dependent, and children have better health outcomes when they are breastfeeding exclusively for longer periods of time, but exclusive breastfeeding has not yet reached its aim due to a variety of factors that contribute to failure.

Objectives: To identify factors affecting the failure of exclusive breastfeeding practice.

Method: The method employed was scoping review, which starts with identifying scoping review questions using the PEO'S framework; selecting relevant articles based on inclusion and exclusion criteria; and finally, evaluating the results. utilizing databases such as Pubmed, Willey Online Library, ProQuest, and Google Scholar to conduct literature searches; Select articles with a PRISMA Flowchart that describes the search process; execute data charting and critical appraisal; compile and report results.

Result: 10 relevant articles have grade A and grade B out of the 103 items that were selected using confidence. Quantitative and qualitative research were used to create these articles. Several factors that influence the inability of exclusive breastfeeding include education \& knowledge, age \& parity, nipple pain, workplace, work facilities, workload, support \& culture.

Conclusion: Internal and external factors influence the success of exclusive breastfeeding, the internal aspects including education and knowledge, age and parity, and nipple pain. Workplace, work facilities, workload, support, and culture all are external factors. The failure of exclusive breastfeeding is influenced by several internal and external factors Therefore, it is hoped that the second factor can be a concern to reduce the incidence of unsuccessful exclusive breastfeeding.

This is an open access article under the CC-BY-SA license. 


\section{Introduction}

Exclusive breastfeeding is very important during the early months of a baby's life because it can reduce infant morbidity and mortality. The World Health Organization (WHO) defines exclusive breastfeeding as feeding infants only with breast milk, excluding other solids or liquids (including formula milk), except medicines, vitamins, and minerals. In 2001, WHO recommended that infants be exclusively breastfed for 6 months in the first age of life (Fox et al., 2015) .

In some countries, exclusive breastfeeding is practiced in a limited number of cases and for a short period of time; on an international scale in 2012, only 39\% of six-month-old babies were exclusively breastfed. This breastfeeding rate falls short of the World Health Organization's recommended threshold (WHO). According to WHO, to reach the global level by 2025 , which is $50 \%$ of mothers must exclusively breastfeed for 6 months after giving birth, a strategy must be developed to encourage and facilitate the initiation and continuation of breastfeeding (Xiao et al., 2020). So, it is hoped that with the target set by (Zakarija-Grkovic \& Stewart, 2020), mothers can give breast milk exclusively to their babies for 6 months optimally.

Exclusive breastfeeding is the ideal nutritional step for infants in the first 6 months of life and it is recommended to continue breastfeeding until the age of 2 years and over (Demirtas, 2018). Adequate nutrition from birth to 2 years of age is an important window for the promotion of children's health and growth. Extensive research has shown that the benefits of breastfeeding are dose-dependent wherein infants will experience better health outcomes with longer durations of exclusive breastfeeding (Desmond \& Meaney, 2016). Although breastfeeding initiation rates are high in most developed countries, the proportion of infants who are breastfed for 6 months drops substantially in the first 3 months. In Hong Kong, current breastfeeding patterns are similar to other developed countries, with $>80 \%$ of women starting breastfeeding, but only $20 \%$ continuing to breastfeed exclusively for 3 months (Fu et al., 2015).

The world records 35 infant deaths per 1000 live births. Indonesia is one of the countries with a high percentage of infant mortality (Elyas et al., 2017). IMR in Indonesia in 2012 decreased by 22 per 1000 live births. However, despite the decline, the percentage of IMR in Indonesia is still quite high when compared to other developing countries which are already below 10 per 1000 baby births.

Recent studies have shown that the hormones in breast milk can affect various areas of a baby's growth, with permanent effects on physiological processes (Francis et al., 2020). It is understood that breast milk can play a role in an individual's predisposition to behaviors, such as aggression and impulsivity (Garrard, 2020; Gildboy \& Bower, 2011). Breast milk has also been shown to affect brain development and has the potential to influence infant behavior and the development of behavioral dispositions. Britton found that mothers who breastfeed can show greater sensitivity in terms of interactions with their children where this initial sensitivity has been used as an independent predictor of any exclusive breastfeeding during the first year (Yate, 2017).

Several factors cause Exclusive Breastfeeding (EBF) failure, including mother's education and mother's occupation, and lack of mother's knowledge. Exclusive breastfeeding is one form of effort to prevent infant mortality while helping to improve the health status of infants. The Special Region of Yogyakarta (DIY) has an exclusive breastfeeding achievement of $73.61 \%$, which is still far from the national target of $80 \%$ (Hashim et al., 2020). This is due to the opinion of mothers who are still wrong in exclusive breastfeeding. Interests and interests, expectations, and culture, experience, and knowledge as a whole can affect exclusive breastfeeding. However, the most influential factor, in this case, is knowledge and experience (Mufdlilah et al., 2018).

Government Regulation (PP) No. 33 of 2012 concerning exclusive breastfeeding Article 6 which states "Every mother giving birth must give exclusive breastfeeding for 6 months," is the government's effort to increase the coverage of exclusive breastfeeding (Mufdlilah et al., 2018). This is following Regional Regulation No. 1 of 2014 Article 3 regarding exclusive breastfeeding. This government regulation aims to guarantee the fulfillment of the baby's right to get breast milk (ASI) exclusively from the baby born until the age of 6 months by looking at its development and growth. Mothers, in this case, will also be given protection during the process of giving exclusive breastfeeding to their babies, increasing the role and support of the community, family, and local government and government regarding exclusive breastfeeding (The Action Study Team et al., 2016). 


\section{Methods}

The method used in this analysis is the scoping review method. The topic in the research that will be studied by the researcher is the findings from articles in previous research journals, namely about the factors that influence the failure of exclusive breastfeeding.

\subsection{Research Question}

Table 1. PEOS Framework

\begin{tabular}{cccc}
\hline $\boldsymbol{P}$ (Population) & E (Exposure) & O (Outcome $)$ & S (Study Research) \\
\hline $\begin{array}{c}\text { Breastfeeding mother } \\
\text { who has baby 0-6 } \\
\text { months }\end{array}$ & Internal Factor & Baby with Exclusive & Qualitative \\
& External Factor & Breastmilk & Quantitative \\
\hline
\end{tabular}

Based on the framework above, the selected scoping review questions are: How can maternal and environmental factors influence failure in exclusive breastfeeding practices?

\subsection{Search Strategy Design}

The databases used in the search for research sources are Pubmed, Wiley Online Library, ProQuest, and Google Scholar. The search was carried out using the Wiley Online Library database which was accessed through the UNISA Library. The search strategy is carried out by entering keywords in the search process, namely ((("unsuccessful") OR ("failure")) AND ("Exclusive Breastfeeding")) OR ("lactating")) OR ("Suckling"). The inclusion criteria in the search for articles were articles published from 2015 to 2020, articles in English, and discussing the factors that influence the failure of exclusive breastfeeding. Article exclusion criteria are articles that are opinion articles or commentaries and book reviews. 


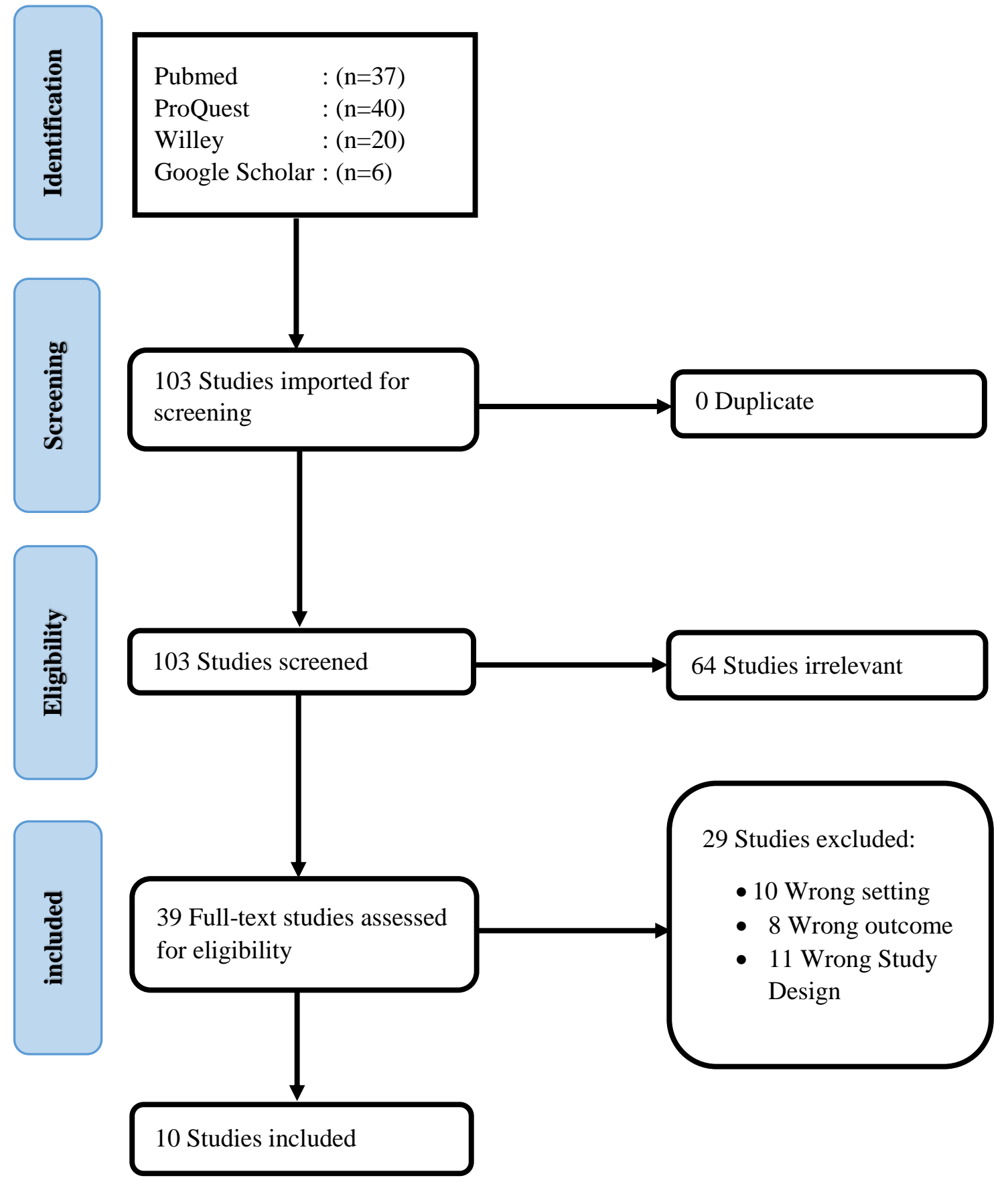

Fig. 1. PRISM Flowchart 
After finding as many as 10 relevant articles to answer this scoping review question, the next step is data charting.

Table 2. Data Charting

\begin{tabular}{|c|c|c|c|c|c|c|c|c|}
\hline No & Title/Author/Year/Grade & Country & Aim & $\begin{array}{l}\text { Type of } \\
\text { Research }\end{array}$ & $\begin{array}{c}\text { Data } \\
\text { Collection }\end{array}$ & $\begin{array}{c}\text { Participants/Sample } \\
\text { Size }\end{array}$ & Result & Theme \\
\hline 1. & $\begin{array}{c}\text { Factors associated with } \\
\text { failure of exclusive } \\
\text { breastfeesing practice. } \\
\text { (Purnamasari \& Mufdlilah, } \\
\text { 2018) }\end{array}$ & Indonesia & $\begin{array}{l}\text { To find out what factor } \\
\text { affecting the process failure } \\
\text { of giving exclusive } \\
\text { breastmilk }\end{array}$ & $\begin{array}{c}\text { Quantitative/cross } \\
\text { sectional }\end{array}$ & Questionnaire & $\begin{array}{l}31 \text { mothers with kids age } \\
0-24 \text { months experiencing } \\
\text { EBF failure }\end{array}$ & $\begin{array}{l}\text { This study shows that a } \\
\text { mother's education and } \\
\text { occupation, as well as } \\
\text { knowledge, have a } \\
\text { relationship with } \\
\text { breastfeeding failure. }\end{array}$ & $\begin{array}{l}\text { Mother factor } \\
\text { Environmental } \\
\text { factor }\end{array}$ \\
\hline 2. & $\begin{array}{l}\text { Factors associated with the } \\
\text { maintenance of breastfeeding } \\
\text { for } 6,12 \text {, and } 24 \text { months in } \\
\text { adolescent mothers. } \\
\text { (Muelbert \& Giugliani, 2018) }\end{array}$ & Brazil & $\begin{array}{l}\text { The purpose of this research } \\
\text { is to identify the factor } \\
\text { which has correlation to } \\
\text { breastfeeding care during at } \\
\text { least } 6,12 \text {, and } 24 \text { months } \\
\text { on adolescent mother. }\end{array}$ & $\begin{array}{l}\text { Quantitative/ } \\
\text { RCT }\end{array}$ & Questionnaire & $\begin{array}{l}\text { Giving counseling to } 323 \\
\text { adolescent mothers }\end{array}$ & $\begin{array}{l}\text { The factors that influence } \\
\text { breastfeeding practice change } \\
\text { over time and with the } \\
\text { expected duration of } \\
\text { breastfeeding practice. White } \\
\text { and primiparous mothers tend } \\
\text { to breastfeed for a shorter } \\
\text { period so more attention } \\
\text { should be paid to when } \\
\text { designing strategies to } \\
\text { improve breastfeeding } \\
\text { practices. Education and } \\
\text { support for adolescent } \\
\text { mothers during the } \\
\text { breastfeeding stage need to be } \\
\text { adapted to have a positive } \\
\text { impact on the mother's } \\
\text { breastfeeding experience. }\end{array}$ & $\begin{array}{l}\text { Mother factor } \\
\text { Environmental } \\
\text { Factor }\end{array}$ \\
\hline 3. & $\begin{array}{c}\text { Exclusive breastfeeding } \\
\text { practices and associated } \\
\text { factors among lactating } \\
\text { mothers of infants aged 6- } \\
24 \text { months in the Kumasi } \\
\text { Metropolis, Ghana. (Yeboah } \\
\text { et al., 2019) }\end{array}$ & Ghana & $\begin{array}{l}\text { Investigating the prevalence } \\
\text { and factor related to EBP } \\
\text { among mothers who give } \\
\text { breastmilk to their baby age } \\
6-24 \text { months. }\end{array}$ & $\begin{array}{l}\text { Quantitative/ } \\
\text { cross sectional }\end{array}$ & Questionnaire & $\begin{array}{l}160 \text { mothers who give } \\
\text { breastmilk to their baby } \\
\text { age among } 6-24 \text { months }\end{array}$ & $\begin{array}{l}\text { This study found that } \\
\text { maternal age, employment } \\
\text { status, parity, mode of } \\
\text { delivery, and nipple pain } \\
\text { were associated with EBP } \\
\text { among breastfeeding mothers } \\
\text { with infants aged between 6- } \\
24 \text { months. }\end{array}$ & Mother's factor \\
\hline
\end{tabular}




\begin{tabular}{|c|c|c|c|c|c|c|c|c|}
\hline 4. & $\begin{array}{l}\text { Cultural Barriers to Exclusive } \\
\text { Breastfeeding by Mothers in } \\
\text { a Rural Area of Cameroon, } \\
\text { Africa. (Kakute et al., 2015) }\end{array}$ & $\begin{array}{c}\text { Kamerun } \\
\text { Afrika }\end{array}$ & $\begin{array}{c}\text { Identifying how far is } \\
\text { giving mixed } \\
\text { food/supplement and } \\
\text { cultural inhibition in giving } \\
\text { exclusive breastmilk }\end{array}$ & $\begin{array}{l}\text { Quantitative/ } \\
\text { survey } \\
\text { methodology }\end{array}$ & Questionnaire & $\begin{array}{l}28 \text { women voluntarily } \\
\text { participated from each } 4 \\
\text { villages with total } 320 \\
\text { participants }\end{array}$ & $\begin{array}{l}\text { Exclusive breastfeeding is not } \\
\text { a common practice by ethnic } \\
\text { groups living in the } \\
\text { Northwest Province of } \\
\text { Cameroon. The women } \\
\text { identified cultural beliefs that } \\
\text { were barriers to exclusive } \\
\text { breastfeeding, even though } \\
\text { they had been encouraged by } \\
\text { local medical care providers. } \\
\text { These beliefs include: Mixed } \\
\text { feeding, breast milk is an } \\
\text { incomplete food source. }\end{array}$ & $\begin{array}{l}\text { Environmental } \\
\text { factor }\end{array}$ \\
\hline 5. & $\begin{array}{l}\text { Breastfeeding Difficulties } \\
\text { and Risk for Early } \\
\text { Breastfeeding Cessation. } \\
\text { (Gianni et al., 2019) }\end{array}$ & Italy & $\begin{array}{l}\text { To know the breastfeeding } \\
\text { difficulty experienced by } \\
\text { the mother with healthy and } \\
\text { sufficient month baby in the } \\
\text { first month after delivery } \\
\text { and their correlation }\end{array}$ & $\begin{array}{c}\text { Quantitative/ } \\
\text { Cross Sectional }\end{array}$ & Questionnaire & $\begin{array}{c}552 \text { couples of mother and } \\
\text { baby in Italy }\end{array}$ & $\begin{array}{l}\text { Our findings provide further } \\
\text { insight into the difficulties } \\
\text { breastfeeding mothers } \\
\text { experience during the first } \\
\text { three months after delivery in } \\
\text { high-income countries. We } \\
\text { underline the importance of } \\
\text { providing continuous tailored } \\
\text { professional support to the } \\
\text { community to overcome } \\
\text { breastfeeding difficulties } \\
\text { experienced by mothers after } \\
\text { discharge from the hospital. }\end{array}$ & $\begin{array}{l}\text { Environmental } \\
\text { factor }\end{array}$ \\
\hline 6 & $\begin{array}{c}\text { Exclusive breastfeeding } \\
\text { practice and associated } \\
\text { factors among mothers in } \\
\text { Motta town, East Gojjam } \\
\text { zone, Amhara Regional State, } \\
\text { Ethiopia, 2015: a cross- } \\
\text { sectional study. (Tewabe et } \\
\text { al., 2016) }\end{array}$ & Ethiopia & $\begin{array}{c}\text { To assess the practice } \\
\text { prevalence of giving } \\
\text { exclusive breastmilk (EBF) } \\
\text { and factors related to the } \\
\text { mother who have baby age } \\
\leq 6 \text { months in City of } \\
\text { Motta, East Gojjam, } \\
\text { Amhara State, Ethiopia. }\end{array}$ & $\begin{array}{c}\text { Quantitative/ } \\
\text { cross-sectional }\end{array}$ & Questionnaire & $\begin{array}{c}\text { In the amount of } 423 \\
\text { mothers with baby age } \\
\text { less than } 6 \text { months } \\
\text { involved in this research. }\end{array}$ & $\begin{array}{l}\text { The prevalence of the } \\
\text { practice of exclusive } \\
\text { breastfeeding is lower than } \\
\text { the level recommended by the } \\
\text { state. A child's age, mother's } \\
\text { occupation, income, } \\
\text { breastfeeding counseling } \\
\text { during antenatal care, } \\
\text { husband's support in } \\
\text { breastfeeding, and colostrum } \\
\text { feeding are independent } \\
\text { factors of exclusive } \\
\text { breastfeeding practice. }\end{array}$ & $\begin{array}{l}\text { Mother's factor } \\
\text { Environmental } \\
\text { factor }\end{array}$ \\
\hline
\end{tabular}




\begin{tabular}{|c|c|c|c|c|c|c|c|c|}
\hline 7 & $\begin{array}{l}\text { Knowledge, attitudes, and } \\
\text { breastfeeding practices of } \\
\text { postnatal mothers: A cross } \\
\text { sectional survey. } \\
\text { (Vijayalakshmi \& Susheela, } \\
\text { 2015) }\end{array}$ & India & $\begin{array}{l}\text { The puroose of this research } \\
\text { is to examine the attitude } \\
\text { and knowledge on } \\
\text { breastfeeding and practice } \\
\text { of giving baby food among } \\
\text { postnatal mother in India. }\end{array}$ & $\begin{array}{c}\text { Quantitative/ } \\
\text { Cross Sectional }\end{array}$ & Questionnaire & 122 Mothers & $\begin{array}{l}\text { The results showed that the } \\
\text { level of exclusive } \\
\text { breastfeeding was low. } \\
\text { Therefore, it is important to } \\
\text { provide prenatal education to } \\
\text { mothers and fathers about } \\
\text { breastfeeding. We also } \\
\text { recommend strengthening } \\
\text { public health education } \\
\text { campaigns to promote } \\
\text { breastfeeding. }\end{array}$ & $\begin{array}{l}\text { Mother's factor } \\
\text { Environmental } \\
\text { factor }\end{array}$ \\
\hline 8 & $\begin{array}{l}\text { Exclusive breastfeeding and } \\
\text { associated factors among } \\
\text { mothers in Gozamin district, } \\
\text { northwest Ethiopia: a } \\
\text { community based cross- } \\
\text { sectional study. (Hunegnaw } \\
\text { et al., 2017) }\end{array}$ & Ethiopia & $\begin{array}{l}\text { To assess the prevalence } \\
\text { and factors related to the } \\
\text { mother who gives exclusive } \\
\text { breastmilk in Gozamin } \\
\text { district, Northwest Ethiopia. }\end{array}$ & $\begin{array}{l}\text { Quantitative/ } \\
\text { Cross Sectional }\end{array}$ & Questionnaire & $\begin{array}{l}506 \text { couples of mother- } \\
\text { baby }\end{array}$ & $\begin{array}{c}\text { Although the estimated } \\
\text { prevalence is relatively high, } \\
\text { more efforts are still needed } \\
\text { to meet WHO } \\
\text { recommendations. Therefore, } \\
\text { we suggest health institutions } \\
\text { encourage in-hospital } \\
\text { deliveries and improve } \\
\text { breastfeeding counseling after } \\
\text { delivery. In addition, } \\
\text { employers also need to } \\
\text { provide longer maternity } \\
\text { leave to improve the practice } \\
\text { of exclusive breastfeeding by } \\
\text { working mothers. }\end{array}$ & $\begin{array}{l}\text { Environmental } \\
\text { factor }\end{array}$ \\
\hline 9 & $\begin{array}{l}\text { Factors Associated with Age } \\
\text { at Breastfeeding Cessation in } \\
\text { Amazonian Infants: Applying } \\
\text { a Proximal-Distal } \\
\text { Framework. (Xuan \& Nhan, } \\
\text { 2018) }\end{array}$ & Brazil & $\begin{array}{l}\text { To assess the potential } \\
\text { social economy factor and } \\
\text { characteristics of mother } \\
\text { and children that can be } \\
\text { connected to the age of quit } \\
\text { breastfeeding }\end{array}$ & $\begin{array}{l}\text { Quantitative/ } \\
\text { cross-sectional }\end{array}$ & Questionnaire & Breastfeeding mother & $\begin{array}{l}\text { The mean breastfeeding } \\
\text { duration in the overall sample } \\
\text { was } 365 \text { days, at which time } \\
\text { there was a significant } \\
\text { decrease in the proportion of } \\
\text { the sample continuing to } \\
\text { breastfeed. This is influenced } \\
\text { by economic factors that } \\
\text { require mothers to work to } \\
\text { meet household needs. }\end{array}$ & $\begin{array}{l}\text { Environmental } \\
\text { factor }\end{array}$ \\
\hline
\end{tabular}


Vol. 4, No. 2, November 2021, pp. 117-129

\begin{tabular}{|c|c|c|c|c|c|c|c|c|}
\hline 10 & $\begin{array}{l}\text { A qualitative exploration of } \\
\text { the sociocultural } \\
\text { determinants of exclusive } \\
\text { breastfeeding practices } \\
\text { among rural mothers. (Joseph } \\
\text { \& Earland, 2019) }\end{array}$ & $\begin{array}{c}\text { North West } \\
\text { Nigeria }\end{array}$ & $\begin{array}{l}\text { Social culture factors that } \\
\text { can have influence on } \\
\text { giving exclusive breastmilk } \\
\text { on mothers in the village }\end{array}$ & $\begin{array}{l}\text { Qualitative/ Cross } \\
\text { Sectional }\end{array}$ & $\begin{array}{c}\text { In-depth } \\
\text { interviews }\end{array}$ & $\begin{array}{c}20 \text { mothers age } 18-39 \\
\text { years old }\end{array}$ & $\begin{array}{l}\text { Three main themes were } \\
\text { obtained from the analysis, } \\
\text { namely initiation of } \\
\text { breastfeeding, exclusive } \\
\text { breastfeeding, and decision- } \\
\text { making about infant feeding. } \\
\text { The six sub-themes included } \\
\text { participants' personal } \\
\text { experiences of infant feeding, } \\
\text { determinants of how soon } \\
\text { breastfeeding was initiated, } \\
\text { and social and cultural } \\
\text { influences on exclusive } \\
\text { breastfeeding practices. } \\
\text { Support from spouses and } \\
\text { relatives is required through } \\
\text { community-based policies } \\
\text { and integrated interventions } \\
\text { that address social and } \\
\text { cultural barriers during the } \\
\text { prenatal and postnatal period }\end{array}$ & $\begin{array}{l}\text { Environmental } \\
\text { factor }\end{array}$ \\
\hline
\end{tabular}




\section{Results/Findings}

Based on the results of critical appraisal on 10 selected articles, good quality was obtained. The next step is to extract data to group the article sections such as objectives, research design, number of samples, and results of the research. From this stage, 9 articles were obtained using quantitative studies (A1, A2, A3, A4, A5, A6, A7, A8, A9) and 1 article using qualitative studies (A10).

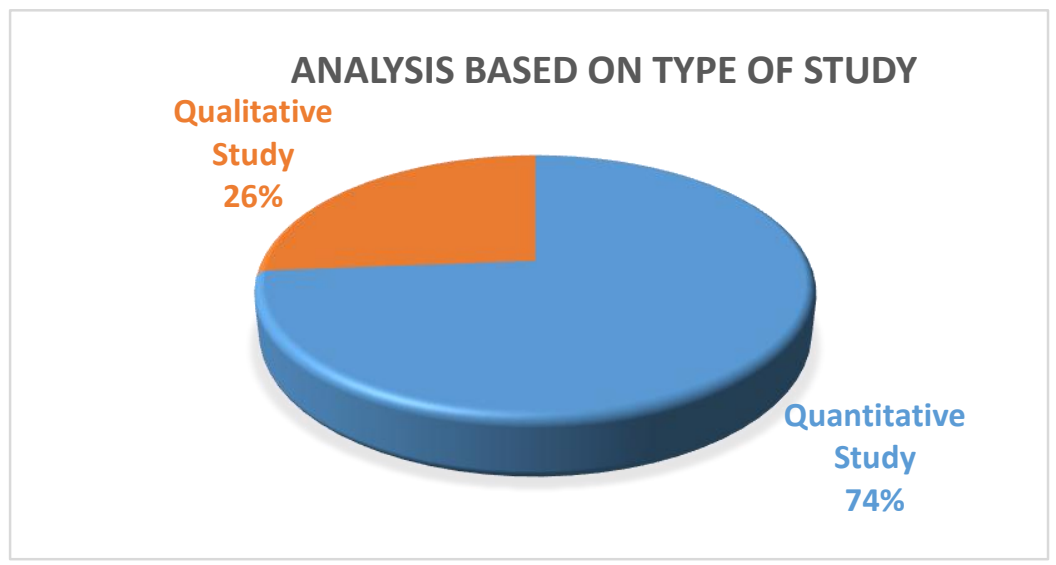

Fig. 2. Diagram of study design

Based on the results of the analysis of the articles taken for this study, it turned out that it was carried out in several countries. These countries include developing countries on the Asian continent where 1 article from Indonesia, 1 article from India. In addition, researches on articles were also conducted in countries on the African continent, namely 4 articles from Ghana, African Cameroon, Nigeria, Ethiopia. While articles from developed countries come from the European continent, such as 1 article from Italy and 1 article from Brazil or the Americas.

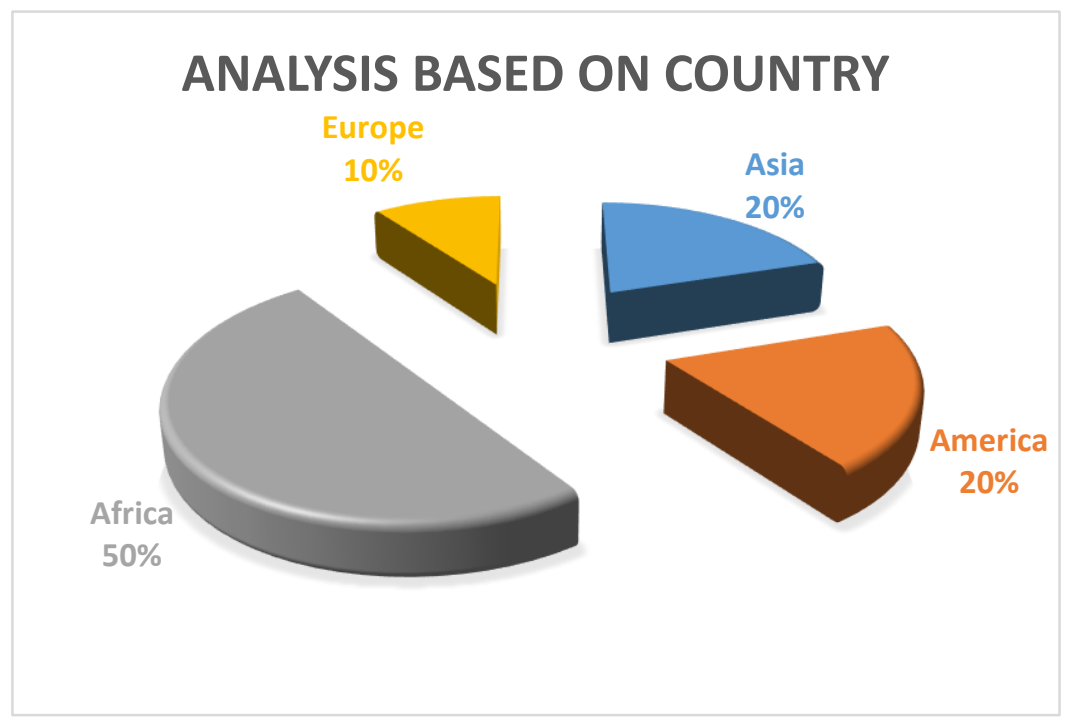

Fig. 3. Country Diagram

Based on the critical appraisal of the selected articles, there were 7 articles including grade A and 3 articles including grade $\mathrm{B}$. 


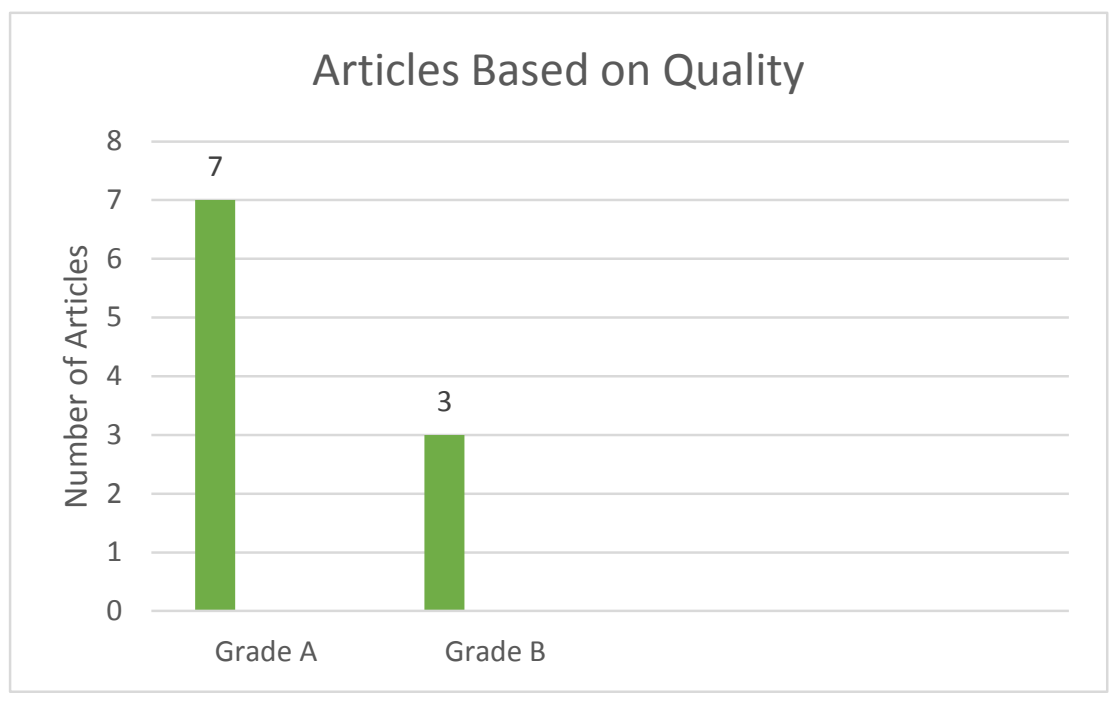

Fig. 4. Grade Diagram

\section{Discussion}

Based on the results of scoping, the researchers drew several themes, namely maternal factors and environmental factors.

\section{1) Maternal Factors}

\section{a) Education \& Knowledge}

Based on (Purnamasari \& Mufdlilah, 2018) the results of Error! Bookmark not defined. research, it was found that knowledge, mother's education, and mother's occupation had an effect on failure during the process of breastfeeding. Factors influencing breastfeeding practice change over time and with the expected duration of breastfeeding practice. White and primiparous mothers tend to breastfeed for a shorter period so more attention should be paid to them when designing strategies to improve breastfeeding practices. Education and support for adolescent mothers during the breastfeeding stage need to be adjusted to have a positive impact on the mother's breastfeeding experience (Muelbert \& Giugliani, 2018).

This finding is in line with the results of research by (Vijayalakshmi \& Susheela, 2015)which shows that the level of exclusive breastfeeding is low. Therefore, it is important to provide prenatal education to mothers and fathers about breastfeeding. We also recommend strengthening public health education campaigns to promote breastfeeding.

\section{b) Age \& Parity}

According to (Muelbert \& Giugliani, 2018) the factors that influence breastfeeding practices change over time and with the expected duration of breastfeeding practices. white and primiparous mothers tend to breastfeed for a shorter period and more attention should be paid to them when designing strategies to improve breastfeeding practices. This study found that maternal age, employment status, parity, mode of delivery, and nipple pain were associated with EBP among breastfeeding mothers with infants aged 6-24 months in the study area (Yeboah et al., 2019).

\section{c) Nipple Pain}

Research conducted by (Yeboah et al., 2019), found that maternal age, employment status, parity, mode of delivery, and nipple pain were associated with EBP among breastfeeding mothers with infants aged 6-24 months in the study area. 
2) Factors of Environmental

a) Workplace, work facilities, workload

The rate of exclusive breastfeeding and lactation practices among female workers is still low. This low number will have an impact on the emergence of many problems related to child health due to the decreasing number of children who can receive the protective health benefits of exclusive breastfeeding. It was noted that women in Ireland due to cultural attitudes and inconsistent advice and not support from professional health workers for breastfeeding mothers become a barrier to achieving exclusive breastfeeding for 6 months. The results of the study found that working mothers had some difficulties breastfeeding their babies. Lack of support and shame because the status of breastfeeding makes some mothers do not want to admit that they are breastfeeding, especially when they return to work. This makes some women do not tell their employers that they are breastfeeding. In addition, they also do not ask about the facilities if they are breastfeeding. there so you can continue to breastfeed when returning to work.

Based on research conducted it was found that employment status was related to EBP among breastfeeding mothers with infants aged 6-24. In this study, it is stated that mothers must return to work immediately so that they do not have time to breastfeed their babies. The prevalence of the practice of exclusive breastfeeding is lower than the level recommended by the state. Mother's work, in the process of breastfeeding and colostrum feeding, is an independent factor from the practice of exclusive breastfeeding.

The average breastfeeding duration in the overall sample was 365 days. There was a significant decrease in the proportion of the sample related to the mother's decision whether to continue breastfeeding or not considering this was also influenced by economic factors that required mothers to work together to help their husbands to meet their household needs.

\section{b) Support \& Culture}

According to the results of research conducted by (Hunegnaw et al., 2017) although the estimated prevalence of successful exclusive breastfeeding is relatively high, more efforts to meet WHO recommendations regarding exclusive breastfeeding are needed. Therefore, we recommend that health institutions continue to encourage hospital deliveries and improve breastfeeding counseling after delivery. Companies in this case also need to provide longer maternity leave for working mothers to improve the implementation process in exclusive breastfeeding.

(Kakute et al., 2015) Stated that exclusive breastfeeding is not a common practice for ethnic groups living in the province of Northwest Cameroon. The women identified cultural beliefs as barriers to exclusive breastfeeding, even though exclusive breastfeeding has received support from local medical care providers. This belief includes mixed feeding because breast milk is an incomplete food source.

(Gianni et al., 2019) Stated that our findings provide further insight into the difficulties breastfeeding mothers experience during the first three months after delivery in high-income countries due to cultural and attitudinal factors. We underscore the importance of providing customized professional support on an ongoing basis in the community to overcome breastfeeding difficulties for mothers after discharge from the hospital. The prevalence of the practice of exclusive breastfeeding is found to be lower than the level recommended by the state. Mother's occupation when breastfeeding and colostrum feeding is an independent factor from the practice of exclusive breastfeeding (Tewabe et al., 2016).

Determinants of how quickly breastfeeding are started and social and cultural influences, influence the practice of exclusive breastfeeding (Basrowi et al., 2018). Support from partners and relatives through community-based policies and integrated interventions that overcome social and cultural barriers during the prenatal and postnatal period is urgently needed which is in line with research in this study, factors that can help the success of exclusive breastfeeding are support $(67.9 \%)$, providing understanding and loving care $(45.3 \%)$, providing individual care $(30.6 \%)$, increasing the confidence of breastfeeding mothers $(25.5 \%)$, and teach them what to do when they experience problems related to breastfeeding (19.1\%). About half of the mothers who experienced breastfeeding problems felt that they were not understood (41.3\%). There are $39.6 \%$ of mothers who cannot interact with nurses. The most cited types of unavailability of nursing services were 
no explanation given due to previous experience (50\%), no effort was made to solve their problems (36.4\%), and lack of responses to breastfeeding women's questions (33.6\%).

\section{Conclusion}

Based on the results of the research conducted and described above, it is concluded that two factors that influence the failure to provide exclusive breastfeeding are external factors and internal factors. These two factors greatly influence each other on the failure to provide exclusive breastfeeding. In other words, these two factors are closely related to achieving the success rate of exclusive breastfeeding.

\section{Acknowledgment}

We would like to thank the Master of Midwifery Faculty of Health Sciences, Aisyiyah University, Yogyakarta for the assistance of facilities to carry out this study.

\section{References}

Basrowi, Sastroasmoro, Sulistomo, Bardosono, Hendarto, Soemarko, Sungkar, Khoe, \& Vandenplas. (2018). Challenges and Supports of Breastfeeding at Workplace in Indonesia. Pediatric $\begin{array}{lllll}\text { Gastroenterology, } \quad \text { Hepatology } \quad \& \quad \text { Nutrition, } & 21(4), & \end{array}$ https://doi.org/10.5223/pghn.2018.21.4.248

Demirtas. (2018). Multiparous mothers: Breastfeeding support provided by nurses. International Journal of Nursing Practice, 21(5), 493-504. https://doi.org/10.1111/ijn.12353

Desmond, \& Meaney. (2016). A qualitative study investigating the barriers to returning to work for breastfeeding mothers in Ireland. International Breastfeeding Journal, 11(1), 16. https://doi.org/10.1186/s13006-016-0075-8

Elyas, Mekasha, Admasie, \& Assefa. (2017). Exclusive Breastfeeding Practice and Associated Factors among Mothers Attending Private Pediatric and Child Clinics, Addis Ababa, Ethiopia: A Cross-Sectional Study. International Journal of Pediatrics, 1-9. https://doi.org/10.1155/2017/8546192

Fox, McMullen, \& Newburn. (2015). UK women's experiences of breastfeeding and additional breastfeeding support: A qualitative study of Baby Café services. BMC Pregnancy and Childbirth, 15(1), 147. https://doi.org/10.1186/s12884-015-0581-5

Francis, Mildon, Stewart, Underhill, Tarasuk, Ruggiero, Sellen, \& O'Connor. (2020). Vulnerable mothers' experiences breastfeeding with an enhanced community lactation support program. Maternal \& Child Nutrition, 16(3). https://doi.org/10.1111/mcn.12957

Fu, Fong, Heys, Lee, Sham, \& Tarrant. (2015). Professional breastfeeding support for first-time mothers: A multicentre cluster randomised controlled trial. BJOG: An International Journal of Obstetrics \& Gynaecology, 121(13), 1673-1683.

Garrard. (2020). Health Science Literature Review Made Easy: The Matrix method (sixth). Jones \& Barttlet Learning.

Gianni, Bettinelli, Manfra, Sorrentino, Bezze, Plevani, Cavallaro, Raffaeli, Crippa, Colombo, Morniroli, Liotto, Roggero, Villamor, Marchisio, \& Mosca. (2019). Breastfeeding Difficulties and Risk for Early Breastfeeding Cessation. Nutrients, 11(10), 2266. https://doi.org/10.3390/nu11102266

Gildboy, \& Bower. (2011). Depression in Primary Care: Evidence and Practice. Cambridge University Press. 
Hashim, Ishak, \& Muhammad. (2020). Unsuccessful Exclusive Breastfeeding and Associated Factors among the Healthcare Providers in East Coast, Malaysia. Korean Journal of Family Medicine, 41(6), 416-421. https://doi.org/10.4082/kjfm.19.0060

Hunegnaw, Gezie, \& Teferra. (2017). Exclusive breastfeeding and associated factors among mothers in Gozamin district, northwest Ethiopia: A community based cross-sectional study. International Breastfeeding Journal, 12(1), 30. https://doi.org/10.1186/s13006-017-0121-1

Joseph, \& Earland. (2019). A qualitative exploration of the sociocultural determinants of exclusive breastfeeding practices among rural mothers, North West Nigeria. International Breastfeeding Journal, 14(1), 38. https://doi.org/10.1186/s13006-019-0231-Z

Kakute, Ngum, Mitchell, Kroll, Forgwei, Ngwang, \& Meyer. (2015). Cultural Barriers to Exclusive Breastfeeding by Mothers in a Rural Area of Cameroon, Africa. Journal of Midwifery \& Women's Health, 50(4), 324-328. https://doi.org/10.1016/j.jmwh.2005.01.005

Muelbert, \& Giugliani. (2018). Factors associated with the maintenance of breastfeeding for 6, 12, and 24 months in adolescent mothers. BMC Public Health, 18(1), 675. https://doi.org/10.1186/s12889-018-5585-4

Mufdlilah, Johan, \& Fitriani. (2018). The Mother's Perception in Giving Exclusive Breastmilk. Journal of Midwifery Research Indonesia, 2(2), 38-44. https://doi.org/10.32536/jrki.v2i1.23

Purnamasari, \& Mufdlilah. (2018). Factors associated with failure of exclusive breastfeeding practice. Journal of Health Technology Assessment in Midwifery, 1(1), 17-22. https://doi.org/10.31101/jhtam.443

Tewabe, Mandesh, Gualu, Alem, Mekuria, \& Zeleke. (2016). Exclusive breastfeeding practice and associated factors among mothers in Motta town, East Gojjam zone, Amhara Regional State, Ethiopia, 2015: A cross-sectional study. International Breastfeeding Journal, 12(1), 12. https://doi.org/10.1186/s13006-017-0103-3

The Action Study Team, K., Castro, Lourenço, Augusto, \& Cardoso. (2016). Factors Associated with Age at Breastfeeding Cessation in Amazonian Infants: Applying a Proximal-Distal Framework. Maternal and Child Health Journal, 20(7), 1539-1548. https://doi.org/10.1007/s10995-016-1953-9

Vijayalakshmi, \& Susheela. (2015). Knowledge, Attitudes and Breastfeeding Practices of Postnatal Mothers: A Cross Sectional Survey. International Journal of Health Sciences, 9(4), 363-372. https://doi.org/10.12816/0031226

Xiao, Loke, Zhu, Gong, Shi, \& Ngai. (2020). "The sweet and the bitter": Mothers' experiences of breastfeeding in the early postpartum period: a qualitative exploratory study in China. International Breastfeeding Journal, 15(1), 12. https://doi.org/10.1186/s13006-020-00256-1

Xuan, \& Nhan. (2018). Breastfeeding experiences of working mothers in Vietnam. Belitung Nursing Journal, 4(1), 279-286.

Yate. (2017). A qualitative study on negative emotions triggered by breastfeeding; Describing the phenomenon of breastfeeding/nursing aversion and agitation in breastfeeding mothers. Iranian Journal of Nursing and Midwifery Research, 2(6), 449. https://doi.org/10.4103/ijnmr.IJNMR_235_16

Yeboah, Forkuor, \& Agyemang-Duah. (2019). Exclusive breastfeeding practices and associated factors among lactating mothers of infants aged 6-24 months in the Kumasi Metropolis, Ghana. BMC Research Notes, 12(1), 689. https://doi.org/10.1186/s13104-019-4723-0

Zakarija-Grkovic, I., \& Stewart, F. (2020). Treatments for breast engorgement during lactation. Cochrane Database of Systematic Reviews, 2020(9). https://doi.org/10.1002/14651858.CD006946.pub4 